\title{
Chemical and bacteriological risks of shrimp and clams (Gandofly) from Suez Gulf
}

\author{
${ }^{1}$ Amin, A.N., ${ }^{1, *}$ Ahemd, A.M. and ${ }^{2}$ Ahmed, O.M. \\ ${ }^{1}$ Department of Food Hygiene, Faculty of Veterinary Medicine, Suez Canal University, Egypt \\ ${ }^{2}$ Department of Fish Processing and Technology, Faculty of Fish Resources, Suez University, Egypt
}

\begin{abstract}
Article history:
Received: 6 November 2020

Received in revised form: 10

December 2020

Accepted: 4 January 2021

Available Online: 13 June

2021
\end{abstract}

Keywords:

Shellfish,

Safety,

Chemical,

Microbial,

Heavy metals

DOI:

https://doi.org/10.26656/fr.2017.5(3).635

\begin{abstract}
Shellfish including shrimp and clams are consumed allover the world for their nutritional value, however, handling in seafood markets may challenge their safety and quality. Shellfish products in the fish markets in Suez Governorate were evaluated throughchemical analysis of total volatile basic nitrogen value, thiobarbituric acid, histamine content, and some heavy metals residues. As well as, microbiological estimation of the total aerobic counts, Enterobacteriaceae counts, Escherichia coli counts, and Staphylococcus aureus counts, in addition of Salmonella detection. Results declared that more than half of the examined samples of shrimp and clams (gandofly) were fit for human consumption based on the permissible limits of the Egyptian standard. Otherwise, some gandofly samples contain high levels of total volatile basic nitrogen (TVB-N), thiobarbituric acid reactive substance (TBA), and may cause scombroid food poisoning with elevated histamine level. The levels of cadmium, lead, and zinc in shellfish samples under study was different with the sequence: $\mathrm{Zn}>\mathrm{Pb}>\mathrm{Cd}$. Bacteria including E. coli and Staphylococcus aureus were identified. The analysed samples in this study were judged as medium/good quality market samples as more than half of the examined samples were within the Egyptian standard and may indicate that trading of shellfish at Suez markets went under abuse storage temperature.
\end{abstract}

\section{Introduction}

Shellfish is consumed all over the world for its nutritional value. Shrimp is highly important in the human diet due to being rich in proteins, fat-soluble vitamins, omega-3, polyunsaturated fatty acids (JavaheriBaboli and Velayatzadeh, 2013). However, in developing countries, the importance of shellfish as a human food source may be under-estimated and its safety and quality are questioned. Most of the infectious outbreaks from seafood appear to be due to shellfish rather than finfish (Butt et al., 2004). Shellfish infection takes place due to the fact they are filter feeders that selectively filter out and concentrate contaminant materials, and microorganism of faecal origin and pathogens adapted to the marine surroundings, and chemical substances (Li et al., 2017). There are a variety of indicators to express the freshness and safety of fish can be estimated by chemicals indicators such as trimethylamine (TMA), total volatile basic nitrogen (TVB-N), Thiobarbituric acid, and histamine production (Li et al., 2017).
The microorganisms' development causes the deterioration of the seafood that leads to losses of quality of the final product. Some microbial groups, such as specific spoilage organisms, are responsible for the negative organoleptic characteristics such as unpleasant taste and smell in fish. In this respect, heavy metals pollution is a public health hazard since these contaminants are widely spread within the environment, including marine environments, from either natural or anthropogenic origins (Lozano et al., 2010). Also, the relevant importance of biogenic amines is their potential toxicity associated with high accumulation and consumption of histamine in fish and fisheries products (Hungerford, 2010).

The objective of this study was to determine the quality and safety of shellfish products (shrimp and bivalve molluscs "clams") in the fish markets in Suez Governorate. Assessments were conducted through: i) chemical evaluation of some indicators (total volatile basic nitrogen value, thiobarbituric acid, histamine content, and some heavy metals residues), ii) bacteriological evaluation of total aerobic count, 
Enterobacteriaceae count, Salmonella, Escherichia coli count, and Staphylococcus aureus count.

\section{Materials and methods}

\subsection{Sampling}

Random shellfish samples (80 samples), 40 of each crustaceans" "shrimp" (imported frozen) and bivalve molluscs "clams" were collected from fish markets at Suez Governorate.

Samples were wrapped in sterile polyethylene bags, identified, and placed in a clean ice-box. Samples were then rapidly transferred to the food control laboratory, Faculty of Veterinary medicine, Suez Canal University under complete aseptic conditions for further evaluation.

\subsection{Chemical evaluation}

\subsubsection{Determination of total volatile basic nitrogen}

According to Malle and Poumeryrol (1989), $100 \mathrm{~g}$ of the pooled shellfish (shrimp - clams) sample extract was dissolved in $200 \mathrm{~mL}$ of $7.5 \%$ aqueous trichloroacetic acid and filtrate the mixture to obtain a clear extract, then blend $25 \mathrm{~mL}$ of this extract with $6 \mathrm{~mL} 10 \% \mathrm{NaOH}$ in a distillation flask. Steam distillation was carried out by using the Kjeldahl-type distillation (Struer TVN)

\subsubsection{Determination of thiobarbituric acid}

Approximately, $1 \mathrm{~g}$ of each sample was taken in a 25 $\mathrm{mL}$ test tube and $5 \mathrm{~mL}$ of $50 \%$ glacial acetic acid in water (AW) as solvent was added. The $0.01 \%$ Butylated hydroxyl toluene (BHT) was used to prevent further oxidation of the medium. The samples were shaken for $1 \mathrm{~h}$ and filtered. The filtrate was centrifuged, when required, and was used for analyses as recommended by Zeb and Ullah (2016).

\subsubsection{Determination of histamine}

According to Patange et al. (2005), $5 \mathrm{~g}$ of shellfish sample transferred to $75 \mathrm{~mL}$ centrifuge, homogenized with $20 \mathrm{~mL}$ of $0.85 \% \mathrm{NaCl}$ solution, and centrifuged at $12000 \times \mathrm{g}$ for $10 \mathrm{mins}$ at $4^{\circ} \mathrm{C}$. The extract $(1 \mathrm{~mL})$ was diluted to $2 \mathrm{~mL}$ with saline and $0.5 \mathrm{~g}$ of a salt mixture containing $6.25 \mathrm{~g}$ of anhydrous sodium sulfate to $1 \mathrm{~g}$ trisodium phosphate monohydrate and was shaken briefly to break the protein gel. The tubes were shacked, then centrifuged at $3100 \times g$ for 10 mins. The upper butanol layer evaporated until dryness in the stream of nitrogen. The residue was dissolved in $1 \mathrm{~mL}$ of distilled water and then mix with p-phenyldiazoniumsulfonate reagent. The colour absorbance was measured after 5 min at $496 \mathrm{~nm}$ using distilled water as a reference and the concentration of histamine was obtained from the standard curve.

\subsubsection{Determination of heavy metal residues}

Shellfish samples washed by deionized water and dried to determine the concentrations of $\mathrm{Cd}, \mathrm{Pb}$ and $\mathrm{Zn}$. Each sample ( $10 \mathrm{~g})$ was digested with a mixture of nitric acid $\left(\mathrm{HNO}_{3}\right.$, Merck, 65\%) and perchloric acid $\left(\mathrm{HClO}_{4}\right.$, Merck, 60\%) with a 2:1 v/v ratio (Canli and Atli, 2003). Tubes were heated in a water bath adjusted to $70^{\circ}$ $\mathrm{C}$, then were cooled at room temperature. Then tubes were diluted with de-ionized water till reach $25 \mathrm{~mL}$ and filtered by Whatman filter paper No. 42. The filtrate kept at room temperature until the analysis of heavy metals. All the digest, blank, and standard solutions were aspirated by the Atomic Absorption Spectrophotometer (AAS). Heavy metals $(\mathrm{Pb}, \mathrm{Cd}$ and $\mathrm{Zn})$ concentrations were analysed by Perkin-Elmer-5100 Atomic Absorption Spectrophotometer.

\subsection{Bacteriological evaluation}

\subsubsection{Sample preparation}

Shrimp frozen samples were held at $4^{\circ} \mathrm{C}$ in the fridge for 6-8 hrs to be thawed. Aseptic technique was undertaken throughout the steps of sample's handling. The shell of clams was scrubbed with a sterile stiff bristle brush under cold potable water to remove the mud with special attention to crevices at the junction of the shells and then placed on a clean paper towel to drain. Closed clam was sterilized by alcohol and then flamed. The adductor muscles were cut with sterile scissors and the covers were removed and transfer the soft tissue to a sterile sample container (ISO, 2013).

Shellfish samples represented by $25 \mathrm{~g}$ of shrimp and clam, separately were added to $225 \mathrm{~mL}$ of $0.1 \%(\mathrm{w} / \mathrm{v})$ sterile buffered peptone water (Oxoid-CM509). The content was homogenized using a Lab Blender (Seward stomacher 400R/UK) for 2 mins. Further tenfold decimal serial dilution up to $10^{-7}$ was carried out.

\subsubsection{Determination of total aerobic plate count}

The total aerobic plate count was carried out by pour plate method in duplicates, using sterile melted plate count agar medium (HI Media, M091) (ISO, 2013). Plates were promptly incubated (Incucell incubator/ Germany) at $30 \pm 1^{\circ} \mathrm{C}$ for $72 \pm 3 \mathrm{hrs}$. Results were reported and expressed as colony forming unit per gram (CFU/g).

\subsubsection{Determination of Enterobacteriaceae}

Enterobacteriaceae count was determined on violet red bile glucose agar medium (VRBG) (HI Media, M091), incubated at $37^{\circ} \mathrm{C}$ for $24 \pm 2 \mathrm{hrs}$ (ISO, 2004). Suspected colonies, which showed purplish-red colonies surrounded by a red zone of precipitated bile acids were enumerated to obtain Enterobacteriaceae count per 
gram.

\subsubsection{Determination of Escherichia coli}

A loopful of sample suspension was aseptically transferred to sterile duplicate plates of MacConkey agar medium (Oxoid, CM015), and incubated at $35 \pm 2^{\circ} \mathrm{C}$ for $18 \pm 2 \mathrm{hrs}$. The colonies grew as pink to brick-red colonies with or without a zone of precipitated bile are lactose fermenting and were picked up and streaked onto sterile duplicate plates of Eosin Methylene Blue agar medium (EMB) (Lap, 61), and incubated at $35 \pm 2^{\circ} \mathrm{C}$ for 18-24 hrs. The typical colony of Escherichia coli is selected were confirmed by Gram's stain, motility test, indole, methyl red, Voges Proskauer, and citrate test (IMVC).

\subsubsection{Determination of Salmonella}

The technique used in this study to detect Salmonella is carried out according to the method described by USA/FSIS (2004) with modification. From the preenrichment broth, $0.1 \mathrm{~mL}$ was separately transferred to $10 \mathrm{~mL}$ Rapport-Vassiliadis broth (Lab, 86) and Tetrathionate broth (Lab, 97), then incubated at $42 \pm 0.5^{\circ}$ $\mathrm{C}$ for 22 hours, and $37 \pm 1^{\circ} \mathrm{C}$ for 24 hours, respectively. Approximately $1 \mathrm{~mL}$ from each broth was plated in duplicates on Salmonella-Shigella agar (S-S) (Himedia, $M$ 108) and Xylose Lysine Deoxycholate (XLD) agar (Lap, 32), then incubated at $35 \pm 2{ }^{\circ} \mathrm{C}$ for $18-24 \mathrm{hrs}$. Suspected Salmonella colonies were identified by Gram staining, motility test, triple sugar iron (TSI) agar, and Lysine Iron Agar. Further confirmation was done by indole test, methyl red, Voges Proskauer, citrate test, and urease test.

\subsubsection{Determination of Staphylococcus aureus}

Pour plate technique was done using Mannitol Salt Agar medium and under aerobic conditions at $35 \pm 2^{\circ} \mathrm{C}$ for 24-48 hrs. The expected result of Staphylococcus aureus is the growth of colonies that have yellow zones at $48 \mathrm{hrs}$ (APHA, 2001).

\subsection{Statistical analysis}

Statistical analysis of data was carried out using Statistical Package for the Social Sciences (SPSS) version 16.0 (SPSS, Inc., Chicago, IL, USA).

\section{Results and discussion}

\subsection{Chemical evaluation}

\subsubsection{Total Volatile Basic Nitrogenous (TVB-N)}

The concentration of TVB-N in the examined samples of shrimp ranged from 52.36 to 68.10 with a mean value of $54.32 \pm 12.03(\mathrm{mg} \mathrm{N} / 100 \mathrm{~g})$, while in clams (gandofly) samples ranged from 50.10 to 70.12 with a mean value of $66.47 \pm 15.84(\mathrm{mg} \mathrm{N} / 100 \mathrm{~g}$ ) (Table 1). Similar results of TVB-N in fish samples were obtained by Ocaño-Higuera et al. (2011).Moreover, 35 $(87.5 \%)$ of shrimp samples and $29(72.5 \%)$ of clams (gandofly) samples are within the permissible limits for TVB-N which is not more than 65 (mg N/100 g). On the other hand, the number of unaccepted samples is 5 $(12.5 \%)$ and $11(27.5 \%)$ of the examined samples of shrimps, and gandofly, respectively. which unaccepted according to the maximal permissible limit for TVB-N as recommended by EOS (2005). TVB-N may be a quality index for unprocessed fishery products, whose increase was related to the activity of spoilage bacteria and endogenous enzymes (Bahmani et al., 2011). The formation of TVB-N is associated with the activity of micro-organisms and tends to be high at high microbial populations as observed by Chytiri et al. (2004). Thus, TVB-N levels are affected by the method of catch, postmortem treatment, and storage temperature as well as it differs according to fish species (Nazemroaya et al., 2011).

\subsubsection{Thiobarbituric acid reactive substances (TBA).}

TBA is a widely used as indicator for the assessment of degree of secondary lipid oxidation (Gulsun et al., 2009). Malondialdehyde (MDA) is one of the most abundant aldehydes generated during secondary lipid oxidation and probably the most used as an oxidation marker (Barriuso et al., 2012). The results indicated that the concentration of TBA in the examined samples of shrimp ranged from 1.88 to 4.60 with a mean value of

Table 1. Results of the chemical analysis of the examined shrimp and clam (gandofly) samples

\begin{tabular}{ccccccc}
\hline & \multicolumn{3}{c}{ Shrimp } & \multicolumn{3}{c}{ Clams (Gandofly) } \\
\cline { 2 - 7 } Item & Mean \pm S.E. & $\begin{array}{c}\text { Accepted } \\
\text { No.(\%) }\end{array}$ & $\begin{array}{c}\text { Unaccepted } \\
\text { No.(\%) }\end{array}$ & Mean \pm S.E. & $\begin{array}{c}\text { Accepted } \\
\text { No.(\%) }\end{array}$ & $\begin{array}{c}\text { Unaccepted } \\
\text { No.(\%) }\end{array}$ \\
\hline TVB-N (mg/100 g) & $54.32 \pm 12.03$ & $35(87.5 \%)$ & $5(12.5 \%)$ & $66.47 \pm 15.84$ & $29(72.5 \%)$ & $11(27.5 \%)$ \\
TBA (mg MDA/Kg) & $2.44 \pm 0.95$ & $38(95 \%)$ & $2(5 \%)$ & $3.18 \pm 1.14$ & $34(85 \%)$ & $6(15 \%)$ \\
Histamine (mg/100 g) & $14.21 \pm 3.46$ & $36(90 \%)$ & $4(10 \%)$ & $16.44 \pm 4.10$ & $32(80 \%)$ & $8(20 \%)$ \\
Pb (mg/Kg wet wt.) & $0.51 \pm 0.101$ & $37(92.5 \%)$ & $3(7.5 \%)$ & $0.60 \pm 0.122$ & $31(77.5 \%)$ & $9(22.5 \%)$ \\
Cd (mg/Kg wet wt.) & $0.20 \pm 0.031$ & $39(97.5 \%)$ & $1(2.5 \%)$ & $0.30 \pm 0.042$ & $38(95 \%)$ & $2(5 \%)$ \\
Zn (mg/Kg wet wt.) & $30.14 \pm 5.10$ & $40(100 \%)$ & $0(0 \%)$ & $32.64 \pm 6.73$ & $40(100 \%)$ & $0(0 \%)$ \\
\hline
\end{tabular}

*S.E. $=$ Standard Error 
$2.44 \pm 0.95$ (mg MDA $/ \mathrm{Kg}$ ), while in clams (gandofly) samples ranged from 2.64 to 4.70 with a mean value of $3.18 \pm 1.14$ (mg MDA/Kg) (table1). Lower results of TBA in shellfish samples were stated by Mohammed et al. (2017) and (Khodanazary, 2019). Furthermore, 38 (95\%) of shrimp samples and 34 (85\%) of clams (gandofly) samples are within the permissible limits for TBA, which is not more than $4.5(\mathrm{mg} \mathrm{MA} / \mathrm{Kg})$. Number of unaccepted samples were $2(5 \%)$ and $6(15 \%)$ of the examined samples of shrimp and clams (gandofly) respectively, which unaccepted according to the maximal permissible limit for TBA as recommended by EOS (2005).

\subsubsection{Histamine content}

Results detected in Table1 that the concentration of histamine in the examined samples of shrimp ranged from 9.88 to 22.58 with a mean value of $14.21 \pm 3.46$ $(\mathrm{mg} / 100 \mathrm{~g})$, while in clams (gandofly) samples ranged from 11.41 to 25.20 with a mean value of $6.44 \pm 4.10$ $(\mathrm{mg} / 100 \mathrm{~g})$. High levels of histamine concentration in shellfish samples compared to this study were obtained by Prester et al. (2010), and lower results were reported by Tam et al. (2017). Also, 36 (90\%) of shrimp samples and $32(80 \%)$ of gandofly samples are within the permissible limits for histamine which is not more than $20(\mathrm{mg} / 100 \mathrm{~g})$. Otherwise, the number of unaccepted samples is $4(10 \%)$ and $8(20 \%)$ of the examined samples of shrimp and gandofly respectively, which unaccepted according to the maximal permissible limit for histamine recommended by EOS (2005). The quantity of biogenic amines produced in seafood relies on the availability of free amino acids, bacterial growth, presence of decarboxylase enzymes and the desired environment for the decarboxylation action (Brink et al. 1990).

\subsubsection{Heavy metal}

It is evident from the results shown in Table 1 that the concentration of lead in the examined samples of shrimp ranged from 0.02 to 1.05 with a mean value of $0.51 \pm 0.101(\mathrm{mg} / \mathrm{Kg}$ wet wt.), while in clams (gandofly) samples ranged from 0.03 to 1.25 with a mean value of $0.60 \pm 0.122$ (mg/Kg wet wt.). Nearly similar results for shrimp and fish samples and higher results for mollusc samples were obtained by Ahmed et al. (2015). Most of the shrimp samples $37(92.5 \%)$ and $31(77.5 \%)$ of gandofly samples are within the permissible limits for the lead as recommended by the Egyptian Standard for lead in fish which is $0.3 \mathrm{mg} / \mathrm{kg}$ wet wt. (EOS 2010). Lead pollution is introduced from many sources such as wastewater treatment sludges to water and soil, transportation, rain, ice, hail and others. Nearly $98 \%$ of lead in the atmosphere initiates from human activates (Amirah et al., 2013).
The concentration of cadmium in the examined samples of shrimp ranged from 0.01 to 0.51 with a mean value of $0.20 \pm 0.031 \mathrm{mg} / \mathrm{Kg}$ wet wt., while clams (gandofly) samples ranged from 0.01 to 0.71 with a mean value of $0.30 \pm 0.042 \mathrm{mg} / \mathrm{Kg}$ wet wt. (Table 1). Further, 39 (97.5\%) of shrimp samples and 38 (95\%) of gandofly samples are within the permissible limits for cadmium as recommended by the Egyptian Standard for cadmium in fish which is $0.05 \mathrm{mg} / \mathrm{kg}$ wet wt. (EOS, 2010). Cadmium happens normally in low amounts in the environment and was also utilized in batteries, pigments, and metal coatings. Industrial processes such as smelting or electroplating and the addition of fertilizers can increase the concentration of $\mathrm{Cd}$ in the environment (Ahmed et al., 2015).

The concentration of zinc in the examined samples of shrimp ranged from 28.22 to 32.11 with a mean value of $30.14 \pm 5.10 \mathrm{mg} / \mathrm{Kg}$ wet wt., while in gandofly samples ranged from 29.74 to 38.21 with a mean value of $32.64 \pm 6.73 \mathrm{mg} / \mathrm{Kg}$ wet wt. (Table 1). Higher results of zinc concentration in shellfish samples were obtained by Ahmed et al. (2015). All shrimp and gandofly samples were within the permissible limits for zinc as recommended by the Egyptian Standard $40 \mathrm{mg} / \mathrm{kg}$ wet wt. (EOS 2005). Generally, the effluent discharges from metallurgic, electroplating, and petrochemical industry, runoffs from agricultural areas and dredging of the harbour and municipal wastes are the sources of zinc in coastal waters. Zinc in the marine environment principally related to suspended substance prior to settling in sediments (Sasikumar et al., 2011). Shellfish species that inhabiting bottom levels have higher capacities for the uptake of heavy metals than others inhabiting the top level due to direct contact with the sediment (Gu et al., 2015).

\subsection{Bacteriological evaluation}

\subsubsection{Total aerobic counts}

Results recorded in Table 2 showed that the mean values of the total aerobic counts were $4.62 \times 10^{4} \pm$ $1.7 \times 10^{3}(\mathrm{CFU} / \mathrm{g})$ for shrimp samples and $6.3 \times 10^{5} \pm$ $2.1 \times 10^{4}(\mathrm{CFU} / \mathrm{g})$ for gandofly samples respectively. Higher results of total aerobic count in shrimp samples were reported by Abd-El-Aziz and Moharram (2016). Lower results were mentioned by Asai et al. (2008) and Mohamed-Hatha et al. (2003). Also, lower results in fish samples were obtained by Sanjee and Karim (2016). Examined samples revealed that $33(82.5 \%)$ of shrimp samples and $28(70 \%)$ of gandofly samples are within the permissible limits for the total aerobic count. On the other hand, $7(17.5 \%)$ and $12(30 \%)$ of the examined samples of shrimp and gandofly, respectively, exceeded the upper permissible limit $\left(1 \times 10^{6} \mathrm{CFU} / \mathrm{g}\right)(\mathrm{EOS}, 2005)$. Aerobic Plate count (APC) indicates quality, not safety; 
Table 2. Statistical analytical results of the bacterial analysis of the examined shrimp and clam (gandofly) samples

\begin{tabular}{ccccccc}
\hline \multirow{2}{*}{ Item } & \multicolumn{2}{c}{ Shrimp } & \multicolumn{3}{c}{ Clams (Gandofly) } \\
\cline { 2 - 7 } & $\begin{array}{c}\text { Mean } \pm \text { S.E. } \\
\left(\log _{10} \text { CFU/g) }\right.\end{array}$ & $\begin{array}{c}\text { Accepted } \\
\text { No.(\%) }\end{array}$ & $\begin{array}{c}\text { Unaccepted } \\
\text { No.(\%) }\end{array}$ & $\begin{array}{c}\text { Mean } \pm \text { S.E. } \\
\left(\log _{10} \text { CFU/g) }\right.\end{array}$ & $\begin{array}{c}\text { Accepted } \\
\text { No. }(\%)\end{array}$ & $\begin{array}{c}\text { Unaccepted } \\
\text { No. }(\%)\end{array}$ \\
\hline Total aerobic counts & $4.62 \times 10^{4} \pm 1.7 \times 10^{3}$ & $33(82.5 \%)$ & $7(17.5 \%)$ & $6.3 \times 10^{5} \pm 2.1 \times 10^{4}$ & $28(70 \%)$ & $12(30 \%)$ \\
Enterobacteriaceae counts & $2 \times 10^{2} \pm 1 \times 10^{2}$ & $38(95 \%)$ & $2(5 \%)$ & $92 \times 10^{1} \pm 2 \times 10^{2}$ & $35(87.5 \%)$ & $5(12.5 \%)$ \\
E. coli counts & $3 \times 10^{2} \pm 1 \times 10^{2}$ & $40(100 \%)$ & $0(0 \%)$ & $50 \times 10^{2} \pm 2 \times 10^{2}$ & $38(95 \%)$ & $2(5 \%)$ \\
S. aureus counts & $8 \times 10^{2} \pm 2 \times 10^{2}$ & $36(90 \%)$ & $4(10 \%)$ & $2.4 \times 10^{3} \pm 3 \times 10^{2}$ & $34(85 \%)$ & $6(15 \%)$ \\
Salmonella & $\mathrm{ND}$ & $40(100 \%)$ & $0(0 \%)$ & ND & $40(100 \%)$ & $0(0 \%)$ \\
\hline
\end{tabular}

$*$ S.E. $=$ Standard Error,$* \mathrm{ND}=$ Non-Detected

it can give useful information about the remaining shelf Ravn et al., 2003).

life and general quality of the food in question.

\subsubsection{Total Enterobacteriaceae counts}

The mean values of the Enterobacteriaceae count in this study were $2 \times 10^{2} \pm 1 \times 10^{2}(\mathrm{CFU} / \mathrm{g})$ for shrimp samples and $92 \times 10^{1} \pm 2 \times 10^{2} \mathrm{CFU} / \mathrm{g}$ for clams (gandofly) samples respectively (Table 2). Nearly similar results of Enterobacteriaceae count in shrimp samples were reported by Abd-El-Aziz and Moharram (2016). Lower results were stated by Onyango (2009) in fish samples. Higher results of Enterobacteriaceae count in mollusc samples were showed by Goulas et al. (2005). Shrimp samples $38(95 \%)$, and $35(87.5 \%)$ of gandofly samples are within the permissible limits for Enterobacteriaceae count. Otherwise, $2(5 \%)$ and $5(12.5 \%)$ of the examined samples of shrimp and gandofly, respectively, exceeded the upper permissible limit which is $10^{2}(\mathrm{CFU} / \mathrm{g})$ as recommended by the Egyptian Standard for Enterobacteriaceae count in shellfish EOS (2005). Enterobacteriaceae count is well-known as an alternative index of seafood quality as its relation to ice storage, rinsing and evisceration (Zambuchini et al., 2008).

\subsubsection{Escherichia coli counts}

The mean values of the $E$ coli count in this study were $3 \times 10^{2} \pm 1 \times 10^{2}(\mathrm{CFU} / \mathrm{g})$ for shrimp samples and $50 \times 10^{2} \pm 2 \times 10^{2} \mathrm{CFU} / \mathrm{g}$ for clams (gandofly) samples respectively (Table 2). Furthermore, $40 \quad(100 \%)$ of shrimp samples and 38 (95\%) of clams (gandofly) samples are within the permissible limits which should be free from pathogenic E. coli. On the other hand, 2 $(5 \%)$ of gandofly samples were not in accordance with the Egyptian standards for pathogenic E. coli count in shellfish EOS (2005). E. coli may transfer to the foods due to poor hygienic conditions, cross-contamination, or contaminated water (Huss et al., 2003). Ineffectively cleaned and sterilized boat decks and fish vessels are also known to contaminate the catch with $E$. coli (Iyer, 2005). Often cited as a potential cause for E. coli contamination is, the quality of the ice used for conservation and the food processing plants (Bagge-

\subsubsection{Salmonella}

In this study, Salmonella spp. was not detected in all examined shellfish samples of shrimp and clams (Table 2), which agrees with the Egyptian standards that $25 \mathrm{~g}$ of shellfish samples must be free from Salmonella spp. (EOS, 2005). The same result was obtained by Marceddu et al. (2017), where all examined seafood samples were free from Salmonella. The possible source of Salmonella contamination in fish farms is may due to bad water quality, farm run off and faecal contamination from wild animals. Generally, sewage pollution of shellfish harvest beds resulted in more shellfish-related outbreaks of Salmonella infections (Iwamoto et al., 2010).

\subsubsection{Staphylococcus aureus counts}

Results of $S$. aureus counts were $8 \times 10^{2} \pm 2 \times 10^{2}$ $\mathrm{CFU} / \mathrm{g}$ for shrimp samples and $2.4 \times 10^{3} \pm 3 \times 10^{2} \mathrm{CFU} / \mathrm{g}$ for gandofly samples respectively (Table 2). Higher results of $S$. aureus count in mollusc samples were stated by Obire et al. (2017). Moreover, 36 (90\%) of shrimp samples and $34(85 \%)$ of gandofly samples are within the permissible limits for $S$. aureus count. Otherwise, 4 $(10 \%)$ and $6(15 \%)$ of the examined samples of shrimp and gandofly, respectively, were exceeded the upper permissible limit which is $10^{3} \mathrm{CFU} / \mathrm{g}$ as recommended by the Egyptian Standard for $S$. aureus count in shellfish (EOS, 2005). Food processing with poor hygienic practice is highly associated with infection of $S$. aureus enterotoxin (Hassanien and Abdel-Aziz, 2017). Food handlers with a hand infection or with cold or with a sore throat may transfer enterotoxigenic strains of Staphylococcus to food (Hammad et al., 2012).

\section{Conclusion}

The results of this study confirmed that marketing of shellfish at Suez markets was carried out under abuse storage temperature. Results of the chemical analysis declare that more than half of the examined samples of shrimp and clams (gandofly) were fit for human consumption based on the permissible limits of the Egyptian standard. Otherwise, some of the examined 
samples mostly gandofly samples contain high levels of TVB-N. Gandofly samples were decomposed in concern to TBA level and may cause scombroid food poisoning in concern to histamine level. The levels of cadmium, lead, and zinc in shellfish samples understudy was different with the sequence: $\mathrm{Zn}>\mathrm{Pb}>\mathrm{Cd}$. These shellfish samples may constitute public health hazards for consumers. Examined samples were contaminant with a satisfactory number of bacteria including pathogens, which represent serious public health hazards for consumers. The analysed samples in this study were judged as medium/good quality market samples.

\section{Conflict of interest}

The authors do not have any conflicts of interest regarding the content of the present work.

\section{References}

Ahmed, W., Gyawali, P. and Toze, S. (2015). Quantitative PCR measurements of Escherichia coli including Shiga toxin producing E. coli (STEC) in animal feces and environmental waters. Environmental Science and Technology, 49(5), 3084 -3090. https://doi.org/10.1021/es505477n

Amirah, M.N., Afiza, A.S., Faizal, W.I.W., Nurliyana, M.H. and Laili, S. (2013). Human Health Risk Assessment of Metal Contamination through Consumption of Fish. Journal of Environment Pollution and Human Health, 1(1), 1-5.

APHA (American Public Health Association). (2001). Compendium of methods for the microbiological examination of food: Technical Committee on Microbiological Methods for Foods. Retrieved on October 5, 2020 from APHA Website: https:// ajph.aphapublications.org/doi/book/10.2105/ MBEF.0222

Bagge-Ravn, D., Ng, Y., Hjelm, M., Christiansen, J.N., Johansen, C. and Gram, L. (2003). The microbial ecology of processing equipment in different fish industries - Analysis of the microflora during processing and following cleaning and disinfection. International Journal of Food Microbiology, 87(3), 239-250. https://doi.org/10.1016/S0168-1605(03) 00067-9

Bahmani, Z.A., Rezai, M., Hosseini, S.V., Regenstein, J.M., Bohme, K., Alishahi, A. and Yadollahi, F. (2011). Chilled storage of golden gray mullet (Liza aurata). Food Science and Technology, 44(9), 18941900. https://doi.org/10.1016/j.lwt.2011.01.009

Barriuso, B., Astiasarán, I. and Ansorena, D. (2012). A review of analytical methods measuring lipid oxidation status in foods: A challenging task.
European Food Research and Technology, 236, 115. https://doi.org/10.1007/s00217-012-1866-9

Brink, B., Damink, C., Joosten, H. and Veld, J.H.J. (1990). Occurrence and formation of biologically active amines in foods. International Journal of Food Microbiology, 11(1), 73-84. https:// doi.org/10.1016/0168-1605(90)90040-C

Butt, A.A., Aldridge, K.E. and Sanders, C.V. (2004). Infections related to the ingestion of seafood. II: parasitic infections and food safety. The Lancet Infectious Disease, 4(5), 294-300. https:// doi.org/10.1016/S1473-3099(04)01005-9

Canli, M. and Atli, G. (2003). The relationships between heavy metal $(\mathrm{Cd}, \mathrm{Cr}, \mathrm{Cu}, \mathrm{Fe}, \mathrm{Pb}$ and $\mathrm{Zn})$ levels and the size of six Mediterranean fish species. Environmental Pollution, 121(1), 129-136. https:// doi.org/10.1016/S0269-7491(02)00194-X

Chytiri, S., Chouliara, I., Savvaidis, I.N. and Kontominas, M.G. (2004). Microbiological, chemical and sensory assessment of iced whole and filleted aquaculture rainbow trout. Journal of Food Microbiology, 21(2), 157-165. https:// doi.org/10.1016/S0740-0020(03)00059-5

Egyptian Organization for Standardization and Quality Control (EOS). (2005). Egyptian Standard of Specifications of Frozen Shrimp (No. 516.). Retrieved from Ministry of Industry and Technological Development, Cairo, Egypt.

Egyptian Organization for Standardization and Quality Control (EOS). (2010). Maximum Levels for certain contaminants in foodstuffs (No 7136/2010). Retrieved from Ministry of Industry and Technological Development, Cairo, Egypt.

Goulas, A.E. and Kontominas, M.G. (2006). Effect of modified atmosphere packaging and vacuum packaging on the shelf life of refrigerated chub mackerel (Scomber japonicas): biochemical and sensory attributes. European Food Research and Technology, 224(5), 545-553. https:// doi.org/10.1007/s00217-006-0316-y

Gu, Y.G., Lin, Q., Wang, X.H., Du, F.Y., Yu, Z.L. and Huang, H.H. (2015). Heavy metal concentrations in wild fishes captured from the South China Sea and associated health risks. Marine Pollution Bulletin, 96 (1-2), 508-512. https://doi.org/10.1016/ j.marpolbul.2015.04.022

Gulsun, O., Esmeray, K., Serhat, O. and Fatih, O. (2009). Sensory, microbiological and chemical assessment of the freshness of red mullet (Mullus barbatus) and gold and goatfish (Upeneusmoluccensis) during storage in ice. Journal of Food chemistry, 114(2), 505-510.

https://doi.org/10.1016/ 
j.foodchem.2008.09.078

Hammad, A.M., Watanabe, W., Fujii, T. and Shimamoto, T. (2012). Occurrence and characteristics of methicillin-resistant andsusceptible Staphylococcus aureus and methicillinresistant coagulase negative staphylococci from Japanese retail ready-to-eat raw fish. International Journal of Food Microbiology, 156(3), 286-289. https://doi.org/10.1016/j.ijfoodmicro.2012.03.022

Hassanien, A.A. and Abdel-Aziz, N.M. (2017). Staphylococcus aureus and their enterotoxin genes in fast food and food handlers from different food premises in Sohag city, Egypt. International Journal of agriculture Science and Veterinary Medicine, 5 (1), 107-113.

Hungerford, J.H. (2010). Scombroid poisoning: a review. Toxicon, 56(2), 231-243. https://doi.org/10.1016/ j.toxicon.2010.02.006

Huss, H.H., Ababouch, L. and Gram, L. (2003). Assessment and Management of Seafood Safety and Quality. FAO Fisheries Technical Paper, 444. Rome: FAO.

ISO (International Organization for Standardization). (2004). Microbiology of food and animal feeding stuffs - Horizontal methods for the detection and enumeration of Enterobacteriaceae - Part 2: Colony -count method (ISO/DIS standard No. 21528-2).

ISO (International Organization for Standardization). (2013). Microbiology of the food chain-Horizontal method for the enumeration of microorganisms-part 1: Colony count at $30^{\circ} \mathrm{C}$ by the pour plate technique (ISO/DIS standard No. 4833-1).

Iwamoto, M., Ayers, T., Mahon, B. and Swerdlow, D.L. (2010). Epidemiology of seafood associated infections in United States. Clinical Microbiological Reviews, 23(2), 399-411. https://doi.org/10.1128/ CMR.00059-09

Iyer, T.S.G. (2005). Faecal indicator bacteria in fish In Quality Assurance in Seafood Processing. Matsyapuri, India: Central Institute of Fisheries Technology.

JavaheriBaboli, M. and Velayatzadeh, M. (2013). Determination of heavy metal and trace elements in the muscles of marine shrimp Fenneropenaeus merguiens is from Persian Gulf Iran. Journal of Animal and Plant Science, 23(3), 786-791.

Khodanazary, A. (2019). Freshness assessment of shrimp Metapenaeus affinis by quality index method and estimation of its shelf life. International Journal of Food Properties, 22(1), 309-319. https:// doi.org/10.1080/10942912.2019.1580719

Li, J., Sun, C., Zheng, L., Jiang, F., Wang, S., Zhuang, Z. and Wang, X. (2017). Determination of trace metals and analysis of arsenic species in tropical marine fishes from Spratly islands. Marine Pollution Bulletin, 122(1-2), 464-469. https://doi.org/10.1016/ j.marpolbul.2017.06.017

Lozano, G., Herraiz, E., Hardisson, A., Gutiérrez, A.J., González-Weller, D. and Rubio, C. (2010). Heavy and trace metal concentrations in three rockpool shrimp species (Palaemon elegans, Palaemonadspersus and Palaemon serratus) from Tenerife (Canary Islands). Environmental Monitoring and Assessment, 168(1-4), 451-460. https://doi.org/10.1007/s10661-009-1126-z

Malle, P. and Poumeyrol, M. (1989). A new chemical criterion for the quality control of fish: trimethylamine/total volatile basic nitrogen (\%). Journal of Food Protocol, 52(6), 419-423. https:// doi.org/10.4315/0362-028X-52.6.419

Marceddu, M., Lamon, S., Consolati, S.G., Ciulli, S., Mazza, R., Mureddu, A. and Meloni, D. (2017). Determination of Salmonella spp., E. coli VTEC, Vibrio spp., and Norovirus GI-GII in Bivalve Molluscs Collected from Growing Natural Beds in Sardinia (Italy). (2017). Foods, 6(10), 88-96. https:// doi.org/10.3390/foods6100088

Nazemroaya, S., Sahari, M.A. and Rezaei, M. (2011). Identification of fatty acid in Mackerel and shark fillets and their change during six months of frozen storage. Agriculture Science Technology Journal, 13 (4), 553-566.

Obire, O., Nwosu, O. and Wemedo, S. (2017). An Evaluation of the Bacteriological Quality of Some Molluscan Shellfish Preserved with Different Drying Methods. Science and Technology, 4(1), 240-253.

Ocaño-Higuera, V.M., Maeda-Martínez, A.N., MarquezRíosc, E., Canizales-Rodríguez, D.F., CastilloYáñez, F.J., Ruíz -Bustos, E., Graciano Verdugo, A.Z. and Plascencia- Jatomea, M. (2011). Freshness assessment of ray fish stored in ice by biochemical, chemical and physical methods. Food Chemistry, 125(1), 49-54. https://doi.org/10.1016/ j.foodchem.2010.08.034

Onyango, D.M. (2009). Isolation of Salmonella and Shigella from imported fish in Winam Gulf of Lake Victoria. Kenya. The Journal of Infection in Developing Countries, 3(2), 99-104. https:// doi.org/10.3855/jidc.56

Patange, S.B., Mukundan, M.K. and Kumar, A.K. (2005). A simple and rapid method for colorimetric determination of histamine in fish flesh. Food Control, 16(5), 465- 472. https://doi.org/10.1016/ j.foodcont.2004.05.008 
Prester, L.J., Orct, T., Macan, J., Vukusic, J. and Kipcic, D. (2010). Biogenic amines and endotoxin in molluscan shellfish. Archives of Industrial Hygiene and Toxicology, 61, 389-397. https:// doi.org/10.2478/10004-1254-61-2010-2049

Sanjee, S. and Karim, M.E. (2016). Microbiological Quality Assessment of Frozen Fish and Fish Processing Materials from Bangladesh. International Journal of Food Science, 2016, 8605689. https:// doi.org/10.1155/2016/8605689

Sasikumar, G., Krishnamoorthy, M., Krishnakumar, P.K. and Bhat, G.S. (2011). Accumulation of trace metals in green mussel Pernaviridis in the shellfish harvesting environment along southern Karnataka coast. Indian Journal of Fisheries, 58(1),53-58.

Tam, L.N., Khu, D.N., Thanh, N.B. and Thi, T.T.V. (2017). Towards Improved Quality Benchmarking and Shelf-Life Evaluation of Black Tiger Shrimp (Penaeus monodon). Food Chemistry, 235, 220-226. https://doi.org/10.1016/j.foodchem.2017.05.055

United State Department of Agriculture (USA), Food Safety and Inspection Service (FSIS). (2004). Microbiology Laboratory guidebook, 3rd ed. Retrieved on October 10, 2020 from FSIS website: https://www.fsis.usda.gov/wps/portal/fsis/topics/ science/laboratories-and-procedures/guidebooks-and -methods/microbiology-laboratory-guidebook/ microbiology-laboratory-guidebook.

Zeb, A. and Ullah, F. (2016). A Simple Spectrophotometric Method for the Determination of Thiobarbituric Acid Reactive Substances in Fried Fast Foods. Journal of Analytical Methods in Chemistry, 2016, 9412767. https:// doi.org/10.1155/2016/9412767 